\title{
Factorial Validation of a Corporate Social Responsibility Perception Scale for Micro, Small, and Medium Enterprises
}

\author{
Martha Ríos Manríquez ${ }^{1 *}$, Celina López Mateo ${ }^{1}$, Julián Ferrer Guerra² \\ ${ }^{1}$ Universidad de Guanajuato, Campus Celaya-Salvatierra, Maxico \\ ${ }^{2}$ Instituto Tecnológico de Celaya, Maxico \\ martha@celaya.ugto.mx*, celinalm@gmail.com, julian.ferrer@itcelaya.edu.mx
}

\begin{abstract}
The aim of this study is obtaining a valid and reliable scale to evaluate the Corporate Social Responsibility perception level (pCSR) of micro, small, and medium-sized Mexican enterprises. A literature review revealed 58 items among 11 dimensions: Ethics, performance, business model changes, quality of working life, the environment, community outreach, marketing, philanthropy, competitiveness, and the interests of stakeholders. A total of 296 companies located in Mexico were considered for the study. Principal axis factoring with varimax rotation was performed with the Exploratory Factorial Analysis Technique (EFA) to give an interpretation to the pCSR in the Mexican context. The factors found are the environment and social commitment, performance, ethics, change in business model, restrictions, and competitiveness. The outcomes show that the scale is valid and reliable for use in evaluating pCSR in micro, small, and medium-sized enterprises. This scale is a tool that allows us to evaluate the social responsibility of micro, small, and medium-sized enterprises, we conclude that considering the characteristics of Latin America, we have provided an original scale to measure pCSR.
\end{abstract}

Keywords: Corporate Social Responsibility, Performance Metrics, Exploratory Factor Analysis, MSMEs

\section{Introduction}

Corporate Social Responsibility (CSR) is a methodology that organizations are incorporating into their businesses for philanthropic reasons due to pressure from stakeholders or for convenience. They adopt CSR as a strategy to improve competitiveness, to become more sustainable, and to improve their quality of life (FUNDES, 2005:26). Both at national and international levels, the ethical behavior of companies, their commitment to the community, the preservation of the environment, and the quality of life of their human capital, are aspects observed by governments, organizations, associations, and researchers. Companies making a product, retailing, or offering a quality service must also commit to aspects such as social marketing, economic retribution to their human capital, community outreach, paying taxes, revenue generation, job creation, environmental training, health, and job security. Among companies' CSR actions are their commitment to develop programs that have a sustainable impact, as much within their internal administration as on the communities in which they operate (CEMEFI, 2008), considering the demands of their different stakeholders (customers, suppliers, workers, community, among others). MSMEs boost innovation, entrepreneurial initiatives, and competitiveness (Spence et al., 2000; Enderle, 2004; Sweeney, 2007; Fisher et al., 2009). However, many believe that small and medium-sized businesses are not interested in being socially responsible, or they do not have the capacity to do so (Castka et al., 2004; ShoenbergerOrgard, 2005; Jenkins, 2004). This could not be further from the truth, as these kinds of companies have flexible operations, rapid communications channels (Margolis, 2001), their business value chain (Argandoña, 2008), and their local involvement. All of this makes these types of companies aware of all their overriding problems.

Enterprises, organizations, and researchers around the world are concerned about the RSC study; it is also true that most Mexican research is based mainly on: ISO26000 (2007), Social Accountability Standard 8000 (Accountability, 2004), the Global Reporting Initiative (GRI, 2009), and the Mexican Norm on Responsibility (IMNC, 2004). However, most of them also take into account certain dimensions from other models. García de la Torre, Portales, and Camacho \& Arandia (2010:98) comment that with the GRI, which includes three elements from TBL, all the others are focused on one or two elements from the Elkington Model. This model called the Triple Bottom Line (TBL) includes economic, social, and environmental dimensions. There are few works about developing constructs about local business in the national and cultural environment, especially in SMEs (Pérez y Veloz, 2007; IMNC, 2004). It is important to know the CSR perception level of the MSMEs. 
Therefore, this work presents the validation of a scale for Mexican enterprises, using Exploratory Factor Analysis (EFA) with extraction factors of the principal components using the Varimax method of orthogonal rotation. This research is considered relevant due to the lack of similar studies on this subject in Mexico, and the need to design specific tools following the ideologies of developing countries.

This paper offers two contributions. The first one is to provide a customized scale to evaluate the level of social responsibility on Mexican SMEs. The second one provides SMEs with feedback on their own business as a guide on how to become a socially responsible enterprise. This research has been structured into five sections. The first one, the introduction, mentions the importance of CSR in SMEs and the research objectives. The following section is a review of the literature, substantiating the importance of the study of CSR and validation through Exploratory Factor Analysis. The third section is concerned with the methodology, describing the original scale. In the fourth section the analysis and results obtained are shown, using the Exploratory Factor Analysis (EFA), with the extraction factors of the principal components, and using the Varimax method of orthogonal rotation.

\section{Literature Review}

The social, economic, and environmental actions of a company from any country "may affect or be affected as a consequence of the organizational's objectives" (Freeman, 1984:46). The spread of CSR in companies is observed by governments, researchers, as well as international and national organizations. Many researchers have developed studies to measure CSR from different perspectives: Organizational results (Zahra \& LaTour, 1987); ethics (Singhapakdi et al., 1995; Singhapakdi et al., 1996); social performance (Kraft \& Hage, 1990; Kraft \& Jauch, 1992; Waddock \& Graves, 1997); financial performance(Aupperle et al., 1985; McWilliams \& Siegel, 2000); labor issues and workers rights; environmental responsibility (Vives, 2005); dimensions of CSR in MSMEs (Nuñez, 2008); tridimensional surveys; knowledge of the company and its products; consumer opinion of CSR; purchase behavior (Vila \&Gimeno-Martínez, 2010); focus on stakeholders (Dopico et al., 2012); strategic variables (Gallardo-Vázquez et al., 2013); the perspective of small business owners (FSB, 2008); the environment, the social aspect, and the performance of the corporate government (KPMG, 2013), among others.

Tools have been developed in Mexico to diagnose CSR in organizations such as the Centro Mexicano para la Filantropía A.C. [Mexican Center for Philanthropy, registered charity in Mexico] (CEMEFI, 2014), which produced a survey that is applied to companies that seek to obtain the ESR® certification. The fundamental areas of this survey are: Quality of life in the company, corporate ethics, community outreach, and care and preservation of the environment. Another organization is the Fundación delEmpresarioChihuahuense, A.C. [The Entrepreneur's Association of Chihuahua, registered charity in Mexico] (FECHAC, 2014), which evaluates four indicators: Quality of life in the company, community outreach, care and preservation of the environment, competitiveness of the company, and the relationship with its stakeholders; this instrument is entirely web based. The agency responsible (Aguilar, 2013), provides statistical data on the CSR of large and MSMES, which is centered on five axes: Reach and structure; implementation; communication; benefits and profitability; and consumer perception. Also, the Mexican Norm in Social Responsibility(IMNC, 2004), which is based on seven dimensions: 1) Ethical values, 2) mutual benefit between the interested parties, 3) leadership,4) personal involvement, 5) process approach, 6)system approach to management, and 7) continuous improvement. Several researchers, such as Husted \& Salazar (2005), contributed an instrument to analyze factors that contribute to companies' motivation to participate in social projects: Profitability and relationships; human capital; social responsibility; competition; and social inclusion. Mercado \& García (2007) evaluated the following variables: Business ethics, environmental preservation, quality of working life, and community outreach.

Initial pCSR Scale: The majority of the aforementioned tools evaluate the environment, quality of life, ethics, competitiveness, profitability, and community. However, despite the range of dimensions that each survey involves, we consider it necessary to look into the indicators in order to determine the companies' CSR perception levels. Therefore, the objectives of this research are: 1) To develop a scale to measure pCSR, 2) to determine the dimensions of the scale, 3 ) to evaluate the reliability and validity of the scale. Taking into 
consideration aspects such as ethics, philanthropy, labor conditions, the environment, commitment to the community, social marketing, restrictions, performance, changes in the management model, obtaining benefits, and the interests of stakeholders, we have the goal of obtaining a tool that measures the companies' socially responsible behavior. In order to determine the dimensions of the new scale proposed in this study, a literature study was first carried out. Eleven dimensions were found: Ethics, performance, changes in the business model, restrictions, quality of working life, the environment, community outreach, marketing, philanthropy, competitiveness, and the interests of the stakeholders (see table 1).

Table 1: Dimensions of the pCSR scale based on the literature review

\begin{tabular}{|c|c|c|c|}
\hline Code & $\begin{array}{l}\text { Initial scale } \\
\text { dimension }\end{array}$ & $\begin{array}{l}\text { Dimension found in } \\
\text { the literature }\end{array}$ & References \\
\hline ETIC & Ethics & Ethics & $\begin{array}{l}\text { CEMEFI (2014); Vitell \& Ramos (2006); } \\
\text { Graafland (2004); Staples (2004); Zinkin } \\
\text { (2004); Dawkins (2004); Uusitalo \& Oksanen } \\
\text { (2004); Foka (2003); Mori (2001); Donaldson } \\
\text { (1996); Pratley (1995); Danley (1999); Vogel } \\
\text { (1986); Zenisek (1979). }\end{array}$ \\
\hline FIL & Philanthropy & Philanthropy & $\begin{array}{l}\text { Saha \& Darnton (2005); Lichtenstein et al. } \\
\text { (2004); Rashid \& Ibrahim (2002); Mori } \\
\text { (2001); Smith \& Alcorn (1991). }\end{array}$ \\
\hline DES & Performance & $\begin{array}{l}\text { Benefits and Business } \\
\text { Sense }\end{array}$ & $\begin{array}{l}\text { Aguilar (2013); Husted \& Salazar(2005); } \\
\text { Núñez (2003). }\end{array}$ \\
\hline MODEG & $\begin{array}{l}\text { Changes to the } \\
\text { business model }\end{array}$ & Business model & $\begin{array}{l}\text { Gallo (2008); Chesbrough \& Rosenbloom } \\
(2002) \text {. }\end{array}$ \\
\hline
\end{tabular}

Ferrer-Balas et al. (2008); Velásquezet al. (2005); Dahle \& Neumayer (2001); Creighton (1999); Riera (1996); Van Ginkel (1996); Meyerson \& Massy (1995).

LAB Labor Employees, quality of conditions life in the company or workplace

CEMEFI (2014); FECHAC (2014); Dopico et al. (2014); Parsons Corporate Social Responsibility Report (2013); Longo et al. (2005); Saha \& Darnton (2005); Ramasamy \& Ting (2004); Staples (2004); Lichtenstein et al. (2004); Mori (2001); Sison (2000); Foss (1973).

MEDAM The The Environment CEMEFI (2014); FECHAC (2014); Parsons Environment Corporate Social Responsibility Report (2013); Saha \& Darnton (2005); Bigné \& Currás (2008); David et al.(2005); Longo et al. (2005); Sasia (2004); Staples (2004); Dawkins (2004); Uusitalo \& Oksanen (2004); Mori (2001); Maignan \& Ferrell (2000); Brown \& Dacin (1997); Zenisek (1979).

COMUN Commitment to Society CEMEFI (2014); FECHAC (2014); Dopico et al. the Community (2014), Parsons Corporate Social Responsibility Report (2013), Longo et al. (2005); Sasia (2004); Ramasamy \& Ting (2004); Lichtenstein et al. (2004); Carroll (2004); Dawkins (2004); Mori (2001); Mohr et al. (2001); Richardson et al. (1999); Baram (1984); Zenisek (1979). 


\begin{tabular}{|c|c|c|c|}
\hline MKT & Marketing & Marketing & $\begin{array}{l}\text { García de los Salmones et al. (2007); Klement } \\
\text { \& Urša (2007); Maignan \& Ferrell (2004); } \\
\text { Singhapakdi et al. (1996); Bagozzi \& } \\
\text { Baumgartner (1994). }\end{array}$ \\
\hline COMP & $\begin{array}{l}\text { Competitivenes } \\
\mathrm{s}\end{array}$ & Competitiveness & $\begin{array}{l}\text { FECHAC (2014); Dopico et al. (2014); Porter \& } \\
\text { Kramer (2006); Husted \& Salazar (2005); } \\
\text { Núñez (2003). }\end{array}$ \\
\hline PRESGI & $\begin{array}{l}\text { Interests of } \\
\text { Stakeholders }\end{array}$ & $\begin{array}{l}\text { Pressure from interest } \\
\text { groups/ Stakeholders }\end{array}$ & $\begin{array}{l}\text { FECHAC (2014); Klement \& Urša (2007); Sasia } \\
\text { (2004); Dawkins \& Lewis (2003); Garvare\& } \\
\text { Isakson (2001). }\end{array}$ \\
\hline
\end{tabular}

Source: Own compilation based on the literature review.

\section{Methodology}

With the aim of obtaining a valid and reliable scale to evaluate the pCSR of micro, small, and medium-sized Mexican enterprises, the Exploratory Factorial Analysis Technique (EFA) was applied, with principal components factor extraction, using the Varimax method of orthogonal rotation. Before this analysis we made a content validation by an expert's panel to ensure the content of each item in the scale. After the EFA, we also run a Reliability analysis: Cronbach's Alpha, Compound Reliability, and Analysis of Variance by Extraction, for the extraction scales were the measures used. Results from these measures are presented later. The quantitative tool was developed based on the Likert five points scale, with answers ranging from completely disagree(1), to completely agree (5). The survey asked 58 items based on the 11 dimensions (see appendix 1).

Technical information about the research: The sample comprised 296 micro, small, and medium-sized enterprises (MSMEs) located in Celaya, Guanajuato, Mexico. There were considered to be companies with at least five employees and an sufficient number of them to determine its social commitment (see table 2).In order to classify the MSMEs, we used Mexican criteria for this (DOF 2009).Regarding the number of employees (micro from 0 - 10, in the commercial, industrial, and service sectors; small from 11 to 50 in the industrial and service sectors, and from 11 to 30 in the commercial sector; medium from 51 to 250 employees in the industrial sector, 51-100 in the service sector, and 31 to 100 in the commercial sector).

Table 2: Technical research data

\begin{tabular}{ll}
\hline Scope & 935 MSMEs with at least 4 employees and up to \\
Country of origin & 250 . (Source: SIEM, 2011) \\
Sample & Mexico \\
Participation index & 296 \\
Sample error & $32 \%$ \\
Reliability & $5 \%$ \\
Sampling method & $95 \%$ \\
Data collection & Simple randomized selection from each stratum. \\
& Survey applied in person to executives or owners. \\
Statistical analysis & Factor analysis, with principal component factors \\
& extraction using the Varimax method of \\
Statistics software & orthogonal rotation. \\
\hline
\end{tabular}

Hypothesis: Once the new scale has been determined, the first hypothesis is as follows:

$\mathrm{H}_{1}$. The perception level of corporate social responsibility (pCSR) in Mexican micro, small and medium-sized enterprises (MSMEs) is determined by ethics, performance, changes in the business model, restrictions, quality of working life, the environment, community outreach, marketing, philanthropy, competitiveness, and pressure from stakeholders.

Having determined the pCSR scale, based on Exploratory Factorial Analysis (EFA), the following hypotheses are proposed: 
$\mathrm{H}_{0}$. The perception levels of corporate social responsibility (pCSR) in Mexican micro, small and medium-sized enterprises (MSMEs) are not determined by the environment or social commitment, performance, ethics, changes in the business model, restrictions, or competitiveness.

$\mathrm{H}_{\mathrm{a}}$. The perception levels of corporate social responsibility (pCSR) in Mexican micro, small, and medium-sized businesses (MSMEs) are determined by the environment, social commitment, performance, ethics, changes in the business model, restrictions, and competitiveness.

\section{Analysis of the pCSR scale and Results}

Content Validity: Once the 58 items of the initial pCSR tool had been determined, it was reviewed by a panel of experts (businessmen and researchers) with the aim of validating its content. Once corrections had been made to the pCSR, we proceeded to apply it in person to the executives and owners of MSMEs. A global Cronbach's Alfaof $\alpha=0.895$ was obtained, which is adequate according to Werts et al. (1974) and Nunally (1978) (considering an acceptable level equivalent to 0.700). However, on analyzing the results by dimension, we observe (see table 3) that 5 of the 11 factors are below $\alpha=0.700$, in particular the dimension of pressure from stakeholders where $\alpha=0.452$.

Table3: Internal components of the initial pCSR

\begin{tabular}{llllllllllllll}
\hline Factors & DES & REST & ETIC & LAB & MEDAM & COMUN & MKT & FIL & COMP & PRESGI & MODEG & Global \\
\hline Items & 8 & 6 & 6 & 5 & 5 & 5 & 8 & 3 & 4 & 3 & 5 & 58 \\
& & & & & & & & & & & & \\
Cronbach's Alfa & 0.839 & 0.704 & 0.775 & 0.677 & 0.826 & 0.668 & 0.641 & 0.614 & 0.768 & 0.452 & 0.804 & 0.895 \\
& & & & & & & & & & & & &
\end{tabular}

Exploratory Factor Analysis: With the purpose of obtaining a robust tool, we proceeded to analyze the data using Exploratory Factorial Analysis (EFA; Reise et al., 2000). In order to ensure the practical meaning, an absolute value of factorial load was considered to be at least 0.600 , considering that this explains an adequate proportion of the variance, and is not elevated (0.800) or abnormal (Hair et al., 2007). At the first attempt, 11 dimensions were considered in the initial tool, finding that the rotation coincides with 12 interactions of 11 extracted components. Of all the variables suggested, 26 were ruled out (see table 4 ) including 4 that were deleted due to the fact that the values oscillated between 0.618 and 0.681 , but only in their interactions (DES7, REST1, REST6, COMUN2, PRESGI1).

Table4: Items deleted from the initial tool (pCSR)

\begin{tabular}{llll}
\hline & Code & Item & $\begin{array}{l}\text { Communalities } \\
\text { Extracted }\end{array}$ \\
\hline 1 & DES4 & Attracting investors & 0.586 \\
2 & DES7 & Reducing fiscal responsibilities & 0.670 \\
3 & REST1 & Increasing costs & 0.531 \\
4 & REST6 & Resisting change & 0.492 \\
5 & COMUN2 & Having received complaints from the community & 0.580 \\
6 & PRESGI1 & Demands from society for social commitment & 0.508 \\
7 & ETIC6 & Partners having denounced acts of corruption & 0.419 \\
8 & LAB1 & Equal hiring practices & 0.399 \\
9 & LAB2 & Development and continuous education & 0.488 \\
10 & LAB3 & Partner participation in CSR projects & 0.467 \\
11 & MEDAM1 & Controlling the environmental impact & 0.459 \\
12 & COMUN1 & Understanding the impact of their activities on the community & 0.508 \\
13 & COMUN3 & Corrective measures for complaints from the community & 0.529 \\
14 & MKT2 & Communication of harm/potential harm of their products & 0.500 \\
15 & MKT3 & Use of technology to reduce risk to the consumer & 0.455 \\
& & Recalling of products due to pressure from consumers and & \\
16 & MKT4 & society & 0.610 \\
17 & MKT5 & Marketing strategy focused on benefitting the company & 0.477
\end{tabular}


18 MKT6

19 MKT7

20 FIL1

21 FIL3

22 COMP3

23 COMP 4

24 PRESGI2

25 PRESGI3

26 MODEG1
Promoting values through marketing strategy

Attending to the demands of their clients

Self-motivation in CSR behavior

Supporting social aspects that the government cannot resolve

Improving job satisfaction

CSR bringing more benefits than costs

Regulation of CSR behavior

CSR behavior having reduced fiscal responsibilities

Impact on production processes
0.642

0.526

0.646

0.544

0.647

0.551

0.585

0.563

0.534

Source: Own elaboration based on an extraction method: Principal Component Analysis.

Regarding the explained variance, the process extracts 22 factors in 11 components, explaining $58.427 \%$ of the original variation (100\%). With the PEARSON correlation matrix, the items were contrasted and confirmed with the Kaiser-Meyer-Olkin coefficient (Kaiser 1970; Cerny and Kiser, 1977), considered a high value(Kaiser 1970,1974). Bartlett's sphericity test (1950) contrasted the existence of a significant correlation between variables $c^{2}=7056.929, \rho<0.01$ at a critical level (significance) of 0.000. However, the data obtained indicate that 4 of the proposed factors to determine pCSR are removed by EFA: Marketing, philanthropy, pressure from stakeholders and community outreach; this last one had 3 items (of which 5 comprised this dimension) with values below 0.580 . The reliability analysis of the tool, observed in table 5, is $\alpha=0.833$, and although it is above 0.700 (recommended by Nunnally, 1978; Churchill, 1979), the dimension of quality of work life obtains $\alpha=0.665$ representing a weak reliability according to George \& Mallery (1995).

Table5: Internal scale consistency, removing 4 factors

\begin{tabular}{lllllllll}
\hline Dimensions & DES & REST & ETIC & LAB & MEDAM & COMP & MODEG & Global \\
\hline $\begin{array}{l}\text { Items } \\
\begin{array}{l}\text { Cronbach's } \\
\text { Alfa }\end{array}\end{array}$ & 6 & 4 & 6 & 2 & 7 & 3 & 4 & 32 \\
\hline
\end{tabular}

Therefore, we proceeded to carry out a second try based on 6 dimensions, with an absolute value of 0.600 , obtaining the following results: The rotation converged to 7 interactions in 6 extracted components. The results indicate that 6 components are capable of reproducing 58.466\% of the original variability (100\% of the variance). In relation to communalities, 6 variables were deleted (DES8, REST5, ETIC4, LAB4, LAB5 and FIL2), as shown in table 6.

Table 6: Deleted items

\begin{tabular}{lllc}
\hline & Code & Item & $\begin{array}{c}\text { Communalities } \\
\text { Extracted }\end{array}$ \\
\hline 1 & DES8 & Improving image & 0.577 \\
2 & REST5 & Not knowing stakeholders & 0.525 \\
3 & ETIC4 & Negotiation that allows providers to grow & 0.417 \\
4 & LAB4 & Incentives and recognition & 0.387 \\
5 & LAB5 & Job satisfaction and corrective action & 0.449 \\
6 & FIL2 & CSR forming part of corporate culture & 0.476 \\
\hline
\end{tabular}

Source: Own elaboration based on an extraction method: Principal Component Analysis.

Having deleted the items with values less than 0.600 , we applied exploratory factorial analysis to the remaining 26 items, with the same data, obtaining a rotation convergence in 6 interactions and 6 extracted components. The results indicate that 6 components are capable of explaining $63.258 \%$ of the original variance (100\%). Contrasting the factors, the Kaiser-Meyer-Olkin (KMO, Kaiser 1970, Cerny \& Kiser, 1977), determined the sample adequacy measurement, $K M O=0.841>0.600$ which is considered to be a high value (Kaiser 1970, 1974). Regarding the null hypothesis (Bartlett, 1950), a significant correlation was found 
between variables $c^{2}=3049.930, \rho<0.01$ at a critical (significant) level of 0.000 . Therefore, the factorial model is adequate to explain the data.

Table7: Variance via Extraction (AVE), compound reliability and Cronbach's Alpha

\begin{tabular}{|c|c|c|c|c|}
\hline Dimensions & $\mathbf{N}$ & $\begin{array}{l}\text { Variance } \\
\text { Via } \\
\text { Extraction } \\
\text { (AVE) }\end{array}$ & $\begin{array}{l}\text { Compound } \\
\text { Reliability }\end{array}$ & $\begin{array}{l}\text { Cronbach's } \\
\text { Alpha }\end{array}$ \\
\hline Environment and social commitment & 7 & 0.604 & 0.914 & 0.861 \\
\hline Performance & 5 & 0.652 & 0.903 & 0.847 \\
\hline Ethics & 5 & 0.595 & 0.880 & 0.819 \\
\hline Changes to the business model & 4 & 0.643 & 0.878 & 0.801 \\
\hline Restrictions & 3 & 0.653 & 0.849 & 0.719 \\
\hline Competitiveness & 2 & 0.727 & 0.842 & 0.719 \\
\hline
\end{tabular}

Reliability Analysis: Cronbach's Alpha, Compound Reliability, and Analysis of Variance by ExtractionIn order to determine the internal composition of the tool, a Cronbach's Alpha test was applied to determine the compound reliability and analysis of variance via extraction (AVE). As can be seen in table 7, the internal composition of all dimensions above $\alpha>0.700$ are considered an adequate alpha value, followed by compound reliability above $\rho c>0.841$, an acceptable value considered to be 0.700 (Werts et al., 1974; Nunally, 1978). Finally, the convergent validity was tested using variance via extraction. All dimensions obtained values above 0.594 (Fornell \& Larcker, 1981) recommend an AVE $>0.594$. Therefore, the factorial model is adequate for explaining the data.

\section{Conclusion and Recommendations}

It is evident that CSR is an important topic worldwide for individuals, businesses, and countries, all concerned about the repercussions of their actions. This research validates a scale that measures the social responsibility perception of MSMEs in a Latin American country, such as Mexico. A robust scale using 26 indicators was developed to measure the pCSR. According to the hypotheses stated in this work, the first hypothesis " $\mathrm{H}_{1}$ was rejected. The level of the perception of corporate social responsibility (pCSR) in micro, small and medium-sized Mexican businesses (MSMEs) is determined by ethics, performance, changes in the business model, restrictions, quality of work life, the environment, community outreach, marketing, philanthropy, competitiveness, and pressure from stakeholders", as the pCSR obtained shows only six dimensions: The environment and social commitment, performance, ethics, changes in the business model, restrictions, and competitiveness, accepting the $\mathrm{H}_{\mathrm{a}}$ hypothesis and rejecting $\mathrm{H}_{0}$. A significant aspect is that the first scale we proposed included the environment as a separate factor from social commitment, and on the new scale these two factors are merged. Therefore, the AFE allowed a pCSR scale to be established that is adequate to explain the data.

Most of the scales are translated to another country in a simple base and they are applied as if they were equal in both countries contexts. In this case we search items according to the literature and integrated them on a scale that was tested in a local context. One limitation of the study was the sample size, which although statistically adequate, the results may have been different if the study were conducted in other states or at a national level, for which one suggested future line of research is to apply the tool to a sample of the entire country. We also suggest that in addition confirmation analysis be performed in order to obtain a structural model of CSR. It is recommended that in the second part of this study a multiple regression analysis be carried out in order to analyze the influence of the factors obtained in the AFE on the level of CSR perception, which may allow the validation from the econometric point of view as a model of the determinants of the level of perception of CSR in a sample of MSMEs for an emerging economy, such as Mexico. Considering that the proposed scale is a tool that allows us to evaluate the social responsibility of micro, small, and medium- 
sized enterprises, we conclude that considering the idiosyncrasies of Latin America, we have provided an original scale to measure pCSR.

Acknowledgment: The authors wish to acknowledge the support of Universidad de Guanajuato (DAIPUGTO) with professional editing assistance.

\section{References}

Accountability. (2004). Accountability for the WBCSD Accountability and Reporting Working Group (Octubre, 2004). Strategic challenges for business in the use of corporate responsibility codes, standards and frameworks.

Aguilar, A. (2013). 1ER Estudio-2013. Panorama de la Responsabilidad Social en México. ResponSable. Available at http://www.responsable.net/estudios/mexico/Panorama_responsabilidad_social_2013

Argandoña, A. (2008). La Responsabilidad Social de lasEmpresasPequeñas y Medianas. Cuadernos de la Cátedra "la Caixa" de Responsabilidad Social de la Empresa y GobiernoCorporativo. No 1.

Aupperle, K. E., Carroll, A. B. \& Hatfield, J. D. (1985). An Empirical Examination of the Relationship between Corporate Social Responsibility and Profitability. Academy of Management Journal, 28(2), 446-463.

Bagozzi, R. P. \& Baumgartner, H. (1994). The Evaluation of Structural Equation Models and Hypothesis Testing. (Eds) Principles of Marketing Research, Cap. 10, Ed. Brasil Blackwell Itd. 386-419.

Baram, M. S. (1984). Charting the Future Course for Corporate Management of Health Risk. American Journal of Public Health, 74(10), 1163-1166.

Bartlett, M. S. (1950). Tests of significance in factor analysis. The British Journal of Psychology, 3, 77-85.

Bigné, E. \& Currás, R. (2008). Influye la Imagen de Responsabilidad Social en la Intención de Compra? El Papel de la Identificación del Consumidor con la Empresa. Universia Business Review, 3, 10-23.

Brown, T. J. \& Dacin, P. A. (1997). The Company and the Product: Corporate Associations and Consumer Product Responses. Journal of Marketing, 61, 68- 84.

Carroll, A. B. (2004). Managing Ethically with Global Stakeholders: A Present and Future Challenge. Academy of Management Executive, 18(2), 114-120.

Castka, P. M. A., Balzarova, C. J., Bamber \& Sharp, J. M. (2004). How can SMEs Effectively Implement the CSR Agenda. A UK Case Study Perspective. Corporate Social Responsibility and Environmental Management. Chichester, 11(3), 140.

CEMEFI. (2014). Centro Mexicano para la Filantropía. Available at http://www.cemefi.org/esr/

CEMEFI. (2008). El Concepto de Responsabilidad Social Empresarial. Available athttp://www.cemefi.org/spanish/content/view/1760/25/

Cerny, C. A. \& Kaiser, H. F. (1977). A study of a measure of sampling adequacy for factor- analytic correlation matrices. Multivariate Behavioral Research, 12(1), 43- 47.

Creighton, S. H. (1999). Greening the Ivory Tower. Improving the Environmental Track Record of Universities, Colleges, and Other Institutions, MIT Press, Cambridge, MA.

Chesbrough, H. \& Rosenbloom, R. S. (2002). The Role of the Business Model in Capturing Value from Innovation: Evidence from Xerox Corporation's Technology Spinoff Companies. Industrial and Corporate Change, 11(3), 529-555.

Churchill, G. A. (1979). A Paradigm for Developing better Measures of Marketing Constructs. Journal of Marketing Research, 16, 64-73.

Dahle, M. \& Neumayer, E. (2001). Overcoming Barriers to Campus Greening. A Survey among Higher Educational Institutions in London, UK. International Journal of Sustainability in Higher Education, 2(2), 139-160.

Danley, J. R. (1999). Corporate Moral Agency. In Frederick, R.E. (Ed,), A Companion to Business Ethic, 243-256. Oxford: Blackwell Publishers.

David, P., Kline, S. \& Dai, Y. (2005). Corporate Social Responsibility Practices, Corporate Identity, and Purchase Intention: A Dual-Process Model. Journal of Public Relations Research, 17(3), 291-313.

Dawkins J. \& Lewis S. (2003). CSR in Stakeholder Expectations and Implication for Company Strategy. Journal of Business Ethics, 44, 185-193.

Dawkins, J. (2004). Corporate Responsibility: The Communication Challenge. Journal of Communication Management, 9(2), 108-119. 
DiarioOficial De La $\quad$ Federación. $\quad$ (2009). Available http://dof.gob.mx/nota_detalle.php?codigo=5096849\&fecha=30/06/2009

Donaldson, T. (1996). Values in Tension: Ethic Away from Home. Harvard Business Review, 74, 48-62.

Dopico, A., Rodríguez, R. \& González, E. (2014). Valoración de la RSC por el Consumidor y Medición de suEfectosobrelasCompras. Revista de Administracão de Empresas, 54(1), 38-52.

Dopico, A., Rodríguez, R. \& González, E. (2012). La Responsabilidad Social Empresarial y los Stakeholders: Un AnálisisClúster. Revista Galega de Economía, 2(1), 1-17.

Enderle, G. (2004). Global Competition and Corporate Responsibilities of Small and Medium-Sized Enterprises. Business Ethics: A European Review, 13(1), 51-63.

FECHAC. (2014). RSE Responsabilidad Social Empresarial. Instrumento de Autodiagnóstico para lasEmpresas. Fundación del EmpresarioChihuahuense, A.C. Available at http://www.fechac.org/pdf/instrumento_de_autodiagnostico_de_rse_para_las_empresas.pdf

Ferrer-Balas, D, J., Adachi, S., Banas, C.I., Davidson, A., Hoshikoshi, A., Mishra, Y., Motodoa, M., Onga\& Ostwald, M. (2008). An International Comparative Analysis of Sustainability Transformations across Seven Universities. International Journal of Sustainability in Higher Education, 9(3), 295-316.

Fisher, K., Geenen, J., Jurcevic,M., Mcclintock, K. \& Davis, G. (2009). Applying Asset-Based Community Development as a Strategy for CSR: A Canadian Perspective on a Win-Win for Stakeholders and SMEs. Business Ethics: A European Review, 18(1), 66-82.

Foka, I. (2003). The FSM: A Holistic Approach to Measuring Ethical and Social Performance. Business Ethics: A European Review, 12(4), 314-324.

Fornell, C. \& Larcker, D. F. (1981). Evaluating structural equation models with unobservable variables and measurement error. Journal of Marketing Research, 18, 39- 50

Foss, L. (1973). Managerial Strategy for the Future: Theory Z Management. California Management Review, 15(3), 68-81.

Freeman, R. E. (1984). Strategic Management: a Stakeholder Approach, Pitman Publishing Company, Massachusetts.

FSB. (2008). Environmental awareness and social responsibility: top small business priorities for 2008. Federation of Small Businesses. The UK's Leading Business Organisation. Available at http://www.fsb.org.uk/news.aspx?REC=4430\&re=news.asp

Fundes. (2005). Situación de la Responsabilidad Social de la Mipyme: El casoChileno. Coordinadopor IKEI, Banco Interamericano de Desarrollo. Available at http://www.fundes.org/uploaded/content/publicacione/1994590089.pdf

Gallardo-Vázquez, D., Sánchez-Hernández, M. I. \& Corchuelo, M. A. B. (2013). Validación de unInstrumento de Medida para la Relación entre la Orientación a la Responsabilidad Social Corporativa y otras Variables Estratégicas de la Empresa. Revista de Contabilidad-Spanish Accounting Review, 16 (1), 1123.

Gallo, P. G. (2008). La Responsabilidad Social EmpresariahaciaunModelo de GestiónSostenible y Responsable, Gi-Gob, Argentina. Available at http://www.cyta.com.ar/biblioteca/bddoc/bdlibros/rse/334_as_fomenta_contribuir.pdf

García de la Torre, C., Portales, L., Camacho, R. G. \& Arandia, P. O. (2010). Instrumento de evaluación de Sustentabilidad y Responsabilidad Social en las Pymes. Revista Administración y Organizaciones.

García de los Salmones, M., Rodríguez del Bosque, I. \& San Martín, H. (2007). The Corporate Social Responsibility as a Marketing Tool: Influence on Consumer Behaviour in Services Sector. 6th International Congress Marketing Trends. París, 26 y 27 de enero.

Garvare, R. \& Isaksson, R. (2001). Sustainable Development - Extending the Scope of Business Excellence Models. Proceedings from the Sixth International Conference on ISO 9000 and TQM, Ayr, April 17-19, 422-427.

George, D. \& Mallery, P. (1995). SPSS/PC + Step by: A Simple Guide and Reference. Belmont: Wadsworth Publishing Company.

Graafland, J. J. (2004). Collusion, Reputation Damage and Interest in Codes of Conduct: The Case of a Dutch Construction Company. Business Ethics: An European Review, 13(2/3), 127-142.

GRI. (2009). Global Reporting Initiative. Recuperada de http://www.globalreporting.org/

Hair, F. J., Anderson, E. R., Tatham, L. R. \& Black C. W. (2007). Análisis Multivariante, Pearson, Prentice Hall, 5ta. edición. 
Husted, C. B. W. \& Salazar, C. J. J. (2005). Un Estudio Exploratoriosobre la Estrategia Social de EmpresasGrandesUbicadas en México. Contaduría y Administración, 215, 9-23.

IMNC. (2004). Directrices para la implementación de un sistema de gestión de responsabilidad social. Instituto Mexicano de Normalización y Generalización. NMX-SAST-004-IMNC-2004.

ISO 26000. (2007). Guidance on Social Responsibility. ISO/TMB WG SR N 143 DRAFT ISO26000WD4.2

Jenkins, H. (2004). A Critique of Conventional CSR Theory: An SME Perspective. Journal of General Management, 29(4), 37-57.

Kaiser, H. F. (1974). An index of factorial simplici-ty. Psychometrika, 39, 31-36.

Kaiser, H. F. (1970). A second generation Little Jiffy. Psychometrika, 35, 401-415.

Klement, P. \& Urša, G. (2007). CSR Expectations: The Focus of Corporate Marketing. Corporate Communications: An International Journal, 12(4), 326 - 340.

KPMG. (2013). The KPMG Survey of Corporate Responsibility Reporting 2013: Executive Summary. KPMG International, December.

Kraft, K. L. \& Hage, J. (1990). Strategy, Social Responsibility and Implementation. Journal of Business Ethics, 9(1), 11-19.

Kraft, K. L. \& Jauch, L. R. (1992). The Organizational Effectiveness Menu: A Device for Stakeholder Assessment. MidAmerican Journal of Business, 7(1), 18-23.

Lichtenstein, D. R., Drumwright, M. E. \& Braig, B. M. (2004). The Effect of Corporate Social Responsibility on Customer Donations to Corporate-Supported Nonprofits. Journal of Marketing, 68(4), 16-32.

Longo, M., Mura, M. \& Bonoli, A. (2005). Corporate Social Responsibility and Corporate Performance: The Case of Italian SMEs. Corporate Governance, 5(4), 28-42.

Maignan I. \& Ferrell, O. C. (2004). Corporate Social Responsibility and Marketing: An Integrative Framework. Academy of Marketing Science Journal, 32(1), 3-19.

Maignan, I. \& Ferrell O. C. (2000). Measuring Corporate Citizenship in Two Countries: The Case of the United States and France. Journal of Business Ethics, 23(3), 283-297.

Margolis, A. (2001). Social Conscience. Financial Management. Caspian Publishing, 7, 34-36.

Mcwilliams, A. \& Siegel, D. (2000). Corporate Social Responsibility and Financial Performance: Correlation or Misspecification? Strategic Management Journal, 21(5), 603-609.

Mercado, S. P. \& García, H. P. (2007). La Responsabilidad Social en Empresas del Valle de Toluca (México). Un Estudio Exploratorio. Estudios Gerenciales, Elsevier, 23(102), 119-135.

Meyerson, J. W. \& Massy, W. F. (1995). Revitalizing Higher Education, Peterson's, Princeton, New Jersey.

Mohr, L. A., Webb, D. J. \& Harris, K. E. (2001). Do Consumers Expect Companies to be Socially Responsible? The Impact of Corporate Social Responsibility on Buying Behavior. Journal of Consumer Affairs, 35(1), 45-72.

Mori. (2001). Annual Corporate Responsibility Study, Available at http:/www.mori.com.

Nunnally, J. C. (1978). Psychometric Theory. New York McGraw Hill, $2^{\text {ns }}$ edition.

Núñez, G. (2003). Responsabilidad Social Corporativa en un Marco de Desarrollo Sostenible, CEPAL- Serie Medioambiente y Desarrollo, No. 72, Naciones Unidas.

Nuñez, G. (2008). Promoting Corporate Social Responsibility in Small and Medium Enterprises in the Caribbean: Survey Result. ECLAC Office in Washington. Available at http://www.cepal.org/washington/publicaciones/xml/7/34237/S3EPR-WAS-L2930i-P.pdf

Parsons Corporate Social Responsibility Report. (2013). People Planet Progress. Corporate social responsibility report. Parsons Delivering a Better World.

Pérez, J. \& Veloz, E. (2007). La responsabilidad social empresarial en México (2000-2007). En Schmukler, B. et al., Cooperación Internacional para el Desarrollo en México. Hacia una agenda participativa. Instituto Mora, México, pp349-391.

Porter, M. E. \& Kramer, M. R. (2006). Strategy and Society: The Link between Competitive Advantage and Corporate Social Responsibility. Harvard Business Review, 84(12), 76-92.

Pratley, P. (1995). The Essence of Business Ethic, Prentice-Hall, London.

Ramasamy, B. \& Ting, H. W. (2004). A Comparative Analysis of Corporate Social Responsibility Awareness: Malaysian and Singaporean Firms. Journal of Corporate Citizenship, 13, 109-123.

Rashid, M. Z. A. \& Ibrahim, S. (2002). Executive and Management Attitudes Towards Corporate Social Responsibility in Malaysia. Corporate Governance, 2(4), 10-16

Reise, S. P., Waller, N. G. \& Comrey, A. L. (2000). Factor Analysis and Scale Revision. Psychological Assessment, 
12(3), 287-297.

Richardson, A. J., Welker, M. \& Hutchinson, I. R. (1999). Managing Capital Market Reactions to Corporate Social Responsibility. International Journal of Management Reviews, 1(1), 17-43.

Riera, P. (1996). Environmental Policy at the Universitat Autonomia de Barcelona", en Leal Filho, W., MacDermot, F. and Padgam, J. (Editores), Implementing Sustainable Development at University Level \pm A Manual of Good Practice, CRE-COPERNICUS, Bradford.

Saha, M. \& Darnton, G. (2005). Green Companies or Green Con-panies: Are Companies Really Green, or are They Pretending to Be? Business and Society Review, 110(2), 117-157.

Sasia, P. M. (2004). La Empresa a Contracorriente. Cuestiones de ÉticaEmpresarial.Ediciones

Shoenberger-Orgard, M. (2005). Sustaining Edges: CSR, Postmodern Play and SMEs. Public Relations Review, 31(4), 578.

Singhapakdi, A., Kraft, K. L., Vitell, S. J. \& Rallapalli, K. C. (1995). The Perceived Importance of Ethics and Social Responsibility on Organizational Effectiveness: A Survey of Marketers. Journal of the Academy of Marketing Science, 23(1), 49- 56.

Singhapakdi, A., Vitell, S. J., Rallapalli, K. C. \& Kraft, K. L. (1996). The Perceived Role of Ethics and Social Responsibility: A Scale Development. Journal of Business Ethics, 15(11), 1131-1140.

Sison, A. J. (2000). Integrated Risk Management and Global Business Ethics, Business Ethics: A European Review, 9(4), 288-295.

Smith, S. M. \& Alcorn, D. S. (1991). Cause Marketing: A New Direction in the Marketing of Corporate Responsibility. Journal of Services Marketing, 5(4), 21-37.

Spence, L. J., Jeurissen, R. \& Rutherfoord, R. (2000). Small Business and the Environment in the UK and the Netherlands: Toward Stakeholder Cooperation. Business Ethics Quarterly, 10(4), 945-965.

Staples, C. (2004). What Does Corporate Social Responsibility Mean for Charitable Fundraising in the UK? International Journal of Nonprofit and Voluntary Sector Marketing, 9(2), 154-158.

Sweeney, L. (2007). Corporate Social Responsibility in Ireland: Barriers and Opportunities Experienced by SMEs when Undertaking CSR. Dublin Institute of Technology, Dublin, Ireland. Corporate Governance - Bradford. Emerald Group Publishing Limited, 7(4), 516-523.

Uusitalo, O. \& Oksasen, R. (2004). Ethical Consumerism: A View from Finland. International Journal of Consumer Studies, 28(3), 214-221.

Van Ginkel, H. J. A. (1996). Implementing Sustainable Development: A Case Study, en Leal Filho, W., MacDermot, F. and Padgam, J. (Editores), Implementing Sustainable Development at University Level \pm A Manual of Good Practice, CRE-COPERNICUS, Bradford.

Velásquez, L. \& Munguía, N. R. (1999). Education for Sustainable Development: The Engineer of the 21st Century. European Journal of Engineering Education, 24(4), 359-70.

Vila, N. \& Gimeno-Martínez, C. (2010). Efectos de la RSC sobre el Consumidor: UnaAplicación al Sector de TransportePúblicoTerrestre. Revista INNOVAR Journal, 20(38), 236-255.

Vitell, S. J. \& Ramos H. E. (2006). The Impact of Corporate Ethical Values and Enforcement of Ethical Codes on the Perceived Importance of Ethics in Business: A Comparison of U. S. and Spanish Managers. Journal of Business Ethics, 64, 31-43.

Vives, A. (2005). Social and Environmental Responsibility in Small and Medium Enterprises in Latin America. Inter-American Development Bank. Sustainable Development Department Dep. Private Enterprise and Financial Markets Sub-Dept. Available at http://idbdocs.iadb.org/wsdocs/getDocument.aspx?DOCNUM=1580939

Vogel, D. (1986). The Study of Social Issues in Management: A Critical Appraisal. California Management Review, 28(2), 142-151.

Waddock, S. A. \& Graves, S. B. (1997). The Corporate Social Performance-Financial Performance Link, Strategic Management Journal, 18(4), 303-319.

Welford, R. (2004). Corporate social responsibility in Europe and Asia: Critical elements and best practice. The journal of Corporate Citizenship, 13(1), 31-47.

Werts, C. E., Linn, R. L. \& Jöreskog, K. G. (1974): Interclass Reliability Estimates. Testing Structural Assumptions. Educational and Psychological Measurement, 34, 25-33.

Zahra, S. A. \& Latour, M. S. (1987). Corporate Social Responsibility and Organizational Effectiveness: A Multivariate Approach. Journal of Business Ethics, 6(6), 459-467. 
Zenisek, T. J. (1979). Corporate Social Responsibility: A Conceptualization Based On Organizational Literature. Academy of Management Review, 4(3), 359-368.

Zinkin, J. (2004). Maximizing the license to operate. CSR from an Asian perspective. Journal of Corporate Citizenship, 14, 67-80.

Appendix 1: Items on the initial scale

\begin{tabular}{|c|c|c|c|c|c|}
\hline & Code & $\begin{array}{l}\text { Items proposed on the } \\
\text { initial scale }\end{array}$ & & Code & $\begin{array}{l}\text { Items proposed on the initial } \\
\text { scale }\end{array}$ \\
\hline 1 & DES1 & $\begin{array}{l}\text { Attracting new clients and } \\
\text { loyalty of existing clients }\end{array}$ & 30 & MEDAM5 & $\begin{array}{l}\text { he activities are linked to the } \\
\text { ompany's strategy } \\
\text { nderstanding the impact of }\end{array}$ \\
\hline 2 & DES2 & Increase in profits & 31 & COMUN1 & $\begin{array}{l}\text { their activities on the life of the } \\
\text { community }\end{array}$ \\
\hline 3 & DES3 & $\begin{array}{l}\text { Improving the quality of the } \\
\text { processes }\end{array}$ & 32 & COMUN2 & $\begin{array}{l}\text { Having received complaints } \\
\text { from the community }\end{array}$ \\
\hline 4 & DES4 & Attracting investors & 33 & COMUN3 & $\begin{array}{l}\text { Corrective measures for } \\
\text { community complaints }\end{array}$ \\
\hline 5 & DES5 & Competitive advantage & 34 & COMUN4 & Taking preventative measures \\
\hline 6 & DES6 & $\begin{array}{l}\text { Employees with high } \\
\text { performance }\end{array}$ & 35 & COMUN5 & $\begin{array}{l}\text { Evaluating the social impacts of } \\
\text { investments and social projects }\end{array}$ \\
\hline 7 & DES7 & $\begin{array}{l}\text { Reducing } \\
\text { responsibilities }\end{array}$ & 36 & MKT1 & $\begin{array}{l}\text { Sponsoring or carrying out } \\
\text { public interest campaigns }\end{array}$ \\
\hline 8 & DES8 & Improving image & 37 & MKT2 & $\begin{array}{l}\text { unicating potential harm } \\
\text { lucts/services }\end{array}$ \\
\hline 9 & REST1 & Increasing costs & 38 & MKT3 & $\begin{array}{l}\text { Use of technology to reduce risk } \\
\text { to the consumer }\end{array}$ \\
\hline 10 & REST2 & $\begin{array}{l}\text { Doubts surrounding social } \\
\text { responsibility }\end{array}$ & 39 & MKT4 & $\begin{array}{l}\text { Recalling of products due to } \\
\text { pressure from consumers and } \\
\text { society }\end{array}$ \\
\hline 11 & REST3 & Financial difficulties & 40 & MKT5 & $\begin{array}{l}\text { Marketing strategies focused on } \\
\text { obtaining benefits for the } \\
\text { company }\end{array}$ \\
\hline 12 & REST4 & Problems incorporating CSR & 41 & MKT6 & $\begin{array}{l}\text { Promoting values through } \\
\text { marketing policy }\end{array}$ \\
\hline 13 & REST5 & Not knowing stakeholders & 42 & & $\begin{array}{l}\text { Attending to the clients' } \\
\text { demands }\end{array}$ \\
\hline 14 & & & 43 & & Considering the clients' needs \\
\hline 15 & ETIC1 & $\begin{array}{l}\text { Ethical principles that guide } \\
\text { the behavior of the partners }\end{array}$ & 44 & FIL1 & Self-motivated CSR behavior \\
\hline 16 & ETIC2 & Legal compliance & 45 & FIL2 & s part of the corporate \\
\hline 17 & ETIC3 & $\begin{array}{ll}\mathrm{g} & \text { against } \\
\mathrm{rs} & \end{array}$ & 46 & FIL3 & $\begin{array}{l}\text { Supporting social projects that } \\
\text { the government cannot resolve }\end{array}$ \\
\hline 18 & ETIC4 & $\begin{array}{l}\text { tiation that allows for } \\
\text { th of suppliers }\end{array}$ & 47 & COMP1 & $\begin{array}{l}\text { ve advantage } \\
\text { mance }\end{array}$ \\
\hline 19 & ETIC5 & $\begin{array}{l}\text { ced relationship: Price- } \\
\mathrm{ct} / \text { service }\end{array}$ & 48 & COMP2 & $\begin{array}{l}\text { Tool for improving customer } \\
\text { and supplier loyalty }\end{array}$ \\
\hline 20 & ETIC6 & $\begin{array}{l}\text { Partners speaking out against } \\
\text { corruption }\end{array}$ & 49 & COMP3 & Improving job satisfaction \\
\hline 21 & LAB1 & Equal hiring practices & 50 & & $\begin{array}{l}\text { CSR having more benefits than } \\
\text { costs }\end{array}$ \\
\hline 22 & LAB2 & $\begin{array}{l}\text { Continuous development and } \\
\text { training }\end{array}$ & 51 & PRESGI1 & $\begin{array}{l}\text { Demands by society for social } \\
\text { commitment }\end{array}$ \\
\hline
\end{tabular}




\begin{tabular}{|c|c|c|c|c|c|}
\hline 23 & LAB3 & $\begin{array}{l}\text { Partner participation in CSR } \\
\text { projects }\end{array}$ & 52 & PRESGI2 & Regulation of CSR behavior \\
\hline 24 & LAB4 & Incentives and recognition & 53 & PRESGI3 & $\begin{array}{l}\text { CSR behavior having reduced } \\
\text { fiscal responsibilities }\end{array}$ \\
\hline & LAB5 & $\begin{array}{l}\text { Job satisfaction and } \\
\text { performing corrective actions }\end{array}$ & 54 & MODEG1 & $\begin{array}{l}\text { Impacts on production } \\
\text { processes }\end{array}$ \\
\hline & MEDAM1 & $\begin{array}{ll}\text { Controlling } & \text { the } \\
\text { environmental impact } & \end{array}$ & 55 & MODEG2 & Impact on the budget \\
\hline & MEDAM2 & $\begin{array}{l}\text { Programs to collect waste and } \\
\text { recycling }\end{array}$ & 56 & MODEG3 & $\begin{array}{l}\text { Changes in the organizational } \\
\text { structure }\end{array}$ \\
\hline & MEDAM3 & $\begin{array}{l}\text { to reduce the environmental } \\
\text { impact }\end{array}$ & 57 & MODEG4 & Impact on company costs \\
\hline & MEDAM4 & $\begin{array}{l}\text { Development of activities to } \\
\text { care for the environment, } \\
\text { linked to company strategy }\end{array}$ & 58 & MODEG5 & Impact on corporate culture \\
\hline
\end{tabular}

Source: Own elaboration based on the literature. 